\title{
Reflections on the Integration of Innovative Entrepreneurship Education and Professional Education
}

\author{
Xuehua Jiang \\ School of Automation and Electrical Engineering \\ Linyi University \\ Linyi, China \\ jxhyx@163.com
}

\author{
Xuemei Pan \\ School of Automation and Electrical Engineering \\ Linyi University \\ Linyi, China \\ panxuemei@lyu.edu.cn
}

\author{
Peijiang Chen \\ School of Mechanical and Vehicle Engineering \\ Linyi University \\ Linyi, China \\ chenpeijiang@163.com
}

\begin{abstract}
In order to meet the needs of the development of new economy, new technology and new industry, China's higher engineering education circle has reached a consensus on the construction of "new engineering", and has inspired the construction of "new engineering". It requires that the education system of "new engineering" should be established in the personnel training system featuring openness, integration and innovation and takes positive results. Conduct effective measures, change the educational concept, optimize the curriculum system, strengthen the construction of teachers, reform the teaching methods, pay attention to the cooperation between school and enterprise, cooperate with people, and build a teaching platform for the integration of production and education. Local colleges and universities should actively connect with regional economic development and industrial transformation, build a guarantee mechanism of integration of production and education, integrate production and education through the whole process of talent training, and explore a new mode of talent training for local colleges and universities to meet the requirements of "new engineering" construction.
\end{abstract}

Keywords-New engineering; Local undergraduate universities, Integration of production and teaching; School-enterprise cooperation; Cooperative education

\section{INTRODUCTION}

At present, with new technology, new formats, new industry situation booming new economy characteristics, industrial upgrading and new energy conversion has been started, especially for the initiative to deal with a new round of technological revolution and the industrial revolution, the national implementation of the innovation driven development and "2025 Chinese manufacturing", "Internet plus", "the large number of According to the implementation of a series of

This study was supported by the the research project to the teaching reform of Shandong province undergraduate colleges in 2015 (No. 2015M060). national strategies such as "cloud computing" and other national strategies, engineers and technicians have put forward higher requirements. It is urgent to accelerate the reform and innovation of engineering education. Since February 2017, the Ministry of education has actively promoted the construction of "new engineering", formed the "Fudan consensus", "Tianjin University action" and "Beijing guide", and published "about the development of the new engineering department". The notifications of research and practice and the notice on promoting the research and practice of the new engineering department have been made to explore the Chinese model and experience of leading the global engineering education to help build a powerful country in higher education [1-2]. In order to raise the new direction for the improvement of the training quality of engineering talents, including applied undergraduate talents, local universities should take the initiative to connect regional economic development and industrial transformation, build a scientific and reasonable quality guarantee mechanism for talent training, cultivate industry knowledge, engineering practice ability, and meet the needs of industrial development. Use type talent. 


\section{THE NEW REQUIREMENTS OF "NEW ENGINEERING" CONSTRUCTION FOR THE TRAINING OF ENGINEERING TALENTS IN LOCAL UNIVERSITIES}

\section{A. The mission of colleges and Universities: from closed training to open education}

The proposal of "new engineering" has pointed out a new direction for improving the quality of engineering talents, including applied undergraduate talents. The new engineering construction, the new engineering department is an upgraded version of "excellent engineer education training plan". It should be oriented to the industry, the world and the future, deepen the reform of engineering education, accelerate the construction of new engineering, and promote the acceleration of China's engineering education into the world's first square. In the face of the construction of "new engineering", local universities should take the initiative to connect regional economic development and industrial transformation and carry out application type transformation and construction. We should take the concept of "new engineering" as the guidance, grasp the direction of the demand of talents in the industry, make full use of local resources, give full play to their own advantages, practice the characteristics of running schools, and deepen the integration of production and education. School enterprise cooperation and cooperative education enhance the students' ability of employment and entrepreneurship, and cultivate a large number of applied and technical skills talents with strong professional background knowledge, engineering practice ability and competent industry development needs, and play a supporting role in regional economic development and industrial transformation and upgrading [3].

\section{B. The concept of training: from knowledge application to application innovation}

Local universities should make clear the goal orientation of cultivating knowledge applied talents, namely, to calculate knowledge and creatively solve practical problems in the application, which is not only different from the training of academic research talents in the subordinate institutions, but also different from the training of skilled personnel in higher vocational colleges. This difference needs to be effectively passed to the students. Reason guides students' learning behavior, guarantees their enthusiasm and improves their quality. Under the background of "new engineering", local universities need to readjust the layout of the professional structure, set up new, new and new disciplines, so that students can adapt themselves to the leading, blend, innovation and development of the new engineering, and train the outstanding engineering talents to lead the future and the Industrial Development in time, and have the innovation. Entrepreneurial ability, effective training of technological innovation and industrial innovation of the application of complex talents, fully play the initiative of students, understand the future themselves to become a person, and actively cooperate with the school education and teaching activities [4].

\section{The structure of teachers: from "knowledge" to "double qualification"}

Under the background of "new engineering", the key to the quality of talent training in local universities lies in the construction of "double quality" teaching staff. The construction of teachers in local universities should be combined with the introduction and part-time job, whether it is introducing full-time teachers, or hiring part-time teachers, the subject background, Knowledge structure, learning structure, work experience and so on should be adapted to the constantly changing new engineering specialty construction, and the industrial practice of the backbone teachers should be given priority. New technology enterprises, well-known enterprises and high level scientific research institutes have built up a team of teachers with rich practical experience, interdisciplinary integration ability, ability to solve complex engineering problems, and ability to deal with future problems. Only the true ability of "double teacher" teachers can guarantee applied undergraduate students.

\section{School-enterprise cooperation: Transformation from internship practice training to production education integration}

In the face of the construction of "new engineering", local universities need to take the initiative to connect regional economic development and industrial transformation, absorb more social forces and create a community of engineering education responsibility for joint business, co construction and sharing, deepen the cooperation between school and enterprise, and from the past simple "practice training base" to "integration of production and education, cooperative education" The transformation of human platform, actively carrying out cooperation research, encouraging enterprises to participate in various education and teaching links in the training of Applied Undergraduate Talents in local colleges and universities, making the reform of the subject to meet the needs of the industry, leading the industrial development, establishing the industrialization college and interdisciplinary integration of new institutions, so as to make the high level of scientific research advantage and production, research and research. The source is transformed into education ecosystem, which promotes the training quality of applied and innovative talents with cross dollar integration [5].

\section{E. External evaluation: from comprehensive assessments to multiple assessments}

The local undergraduate colleges and universities have experienced the evaluation and audit evaluation of the undergraduate teaching work level, and now they have entered the "five in one" evaluation stage with Chinese characteristics in the new period. Through the formative evaluation, the problems in the construction and training process are found, and the corresponding solutions are put forward to promote the improvement of the training quality. In the context of the "new engineering", the accreditation of engineering education is strengthened and the three party evaluation and so on. The training quality and employment quality of applied talents after cross disciplinary integration, and guided by the current needs 
and future development of the industry, will continuously improve the quality of personnel training.

\section{FROM THE "NEW ENGINEERING" CONSTRUCTION, THE PROBLEMS EXISTING IN LOCAL UNDERGRADUATE COLLEGES AND UNIVERSITIES}

\section{A. Teachers don't know enough about the positioning of applied undergraduate talents}

"Based on the local, to cultivate applied talents as the main goal, directly for regional economic construction and social development service" is the local undergraduate training and positioning. Although most teachers have recognized the location of the talent training in the school, many teachers have not enough knowledge of applied talents. In the process of teaching and educating people, many colleges and universities understand the integration of production and education by signing agreements between schools and enterprises and institutions and solving the problems of student internship and employment placement. At the same time, there are few studies on the problems of model construction, system innovation, policy arrangement, system construction and campus culture construction, and the research in the micro fields of professional and curriculum reform, entrepreneurship education, process management, case study, and predicament analysis. Colleges and universities have not infiltrated the concept of integration of production and education into the various links of talent training, and have not deeply thought about how to serve the enterprises and institutions and how to promote regional economic development. Due to the lack of understanding, the power of deep integration of practice teaching is insufficient [6].

\section{B. Curriculum system can't meet the needs of "new engineering" talent training}

Curriculum as a basic element of talent training, the rationality of curriculum directly affects the quality of personnel training. The major curriculum system of local undergraduate colleges mainly includes three parts: theory teaching, practice teaching and quality development. The theory teaching system mainly includes two parts of the public class and the professional course; the practical teaching mainly includes the experiment course, the professional practice, the curriculum design, they graduation thesis design and so on. The development of the quality mainly includes the social practice, the scientific and technological activities, the discipline competition, the innovation and entrepreneurship training and so on. In the actual teaching process, theoretical teaching and practice teaching can cover all students, but the quality expansion is often the participation of individual students [7].

\section{The construction of "double-quality" teachers is not enough}

The quality of school teachers determines the quality of talent training. The training of "new engineering" talents in local universities have put forward higher requirements for the construction of teachers: not only a solid theoretical teaching level, but also strong practical guidance ability. That is to say, we need to build a double quality teacher team. The new young teachers in local universities have a higher proportion of young teachers and have a certain practical ability, but the teaching experience is insufficient and it needs a period of growth to become the backbone teachers. And with the development of society, the transformation and upgrading of local enterprises closely combine with the progress of the current science and technology. If the teachers of local universities fail to catch up with the needs of social development in time, it is very likely that the school enterprise should be decoupled from the college and enterprise, and the teachers can't meet the technical needs of the enterprise transformation. The opportunities for practical training will be reduced, and the external technical teachers are not put into practice. The teachers of "Double Teachers" are less. The teachers' structure can't meet the requirements of the construction of "new engineering", and the quality of the training of applied new engineering talents is finally affected.

\section{The construction of the practical teaching system is not perfect}

Some achievements have been made in the construction of the training system of practical teaching in local universities, but there is still a large space for the construction of the application type "new engineering" talent training. The first is that most of the current practice teaching system is still attached to the traditional classroom theory teaching content, so that the students' practical training ability and the actual engineering application capacity needs a larger gap, and the needs of the local industry development applied talents are weak. The two is the strength and low utilization rate of training base. In the process of building the training base, the purchase equipment can't meet the needs of the local industry and industry, and the degree of opening to the students is not enough. Part of the off campus practice base has a phenomenon of "flying around". Students are just visiting, and can't do hands-on practice in enterprises. In practice, there is a lack of faculty participation in local enterprises. 


\section{THE CONSTRUCTION OF TALENT TRAINING MECHANISM FOR DEEP INTEGRATION OF INDUSTRIES AND EDUCATION}

\section{A. Facing the construction of "new engineering", change the concept of talent cultivation and education}

Let professional teachers fully understand the urgency and necessity of "new engineering" construction, and clarify their roles and responsibilities in the training of new engineering talents. We should set up the correct concept of applied talents training, recognize the situation and face difficulties and progress. Actively participate in the construction of "new engineering", and improve their professional practice ability and practical teaching level through training and learning. We should pay attention to excavating the elements of the integration of various professional teaching and teaching, and find the right combination point, carry out the teaching of professional courses appropriately, train the practical ability in the course of the teaching, encourage the students to make use of their professional knowledge and innovative learning achievements to carry out professional practice, and establish the students' development of the new industry through "doing middle school and learning in learning". Characteristics and industry have basic cognition to the ability requirements of professional technicians, strengthen the goal and motivation of professional learning, excavate students' potential, stimulate their interest in learning, and cultivate their application and innovation ability [8].

\section{B. Adapt to the construction of "new engineering" and set up a professional system to serve local development}

The local application-oriented universities should closely follow the adjustment of the national industrial structure and the development trend of regional industries and industries, and constantly optimize and adjust their professional structure and layout, and set up special specialties adapted to the development of the regional economic and social development. By building applied professional groups, we can gradually improve the construction of curriculum system, professional planning and local industry planning, professional chain and industrial chain, curriculum content and professional standards, teaching process and production process, and systematically train technical skills talents, and establish close docking of local industrial chain and create a close connection. To ensure that the professional clusters of the school enterprise cooperation are fully covered by the main major, and the high level and high level of Applied Universities with outstanding advantages and distinctive features are built to serve the implementation of the strategy of entrepreneurship and development in the local economic zone.

\section{Through the construction of "new engineering", improve "double quality" teachers}

The local application-oriented universities should focus on the standards and requirements of enterprises and industries, carefully analyze the current situation of teachers' structure, adopt corresponding measures and policies to adjust the teachers' structure, and ensure that the "double teachers and double energy" teachers make up a certain proportion of the full-time teachers and create a "double teacher dual energy type" teacher team which is increasingly rational in structure. The training of applied talents emphasizes the training of students' technological skills and innovation ability, which requires teachers' teaching ability to meet the requirements of professional post masters.

\section{Relying on the construction of "new engineering", comprehensively deepen the cooperation between schools and enterprises}

The integration of production and education focuses on the integration of schools and enterprises, which runs through the whole process of talent training. The local application-oriented universities should take the difficult problems in the process of industrial transformation and upgrading as the main direction of service, think about how to meet the needs of the enterprises, drive the curriculum reform with the social economic development and the industrial technology progress, and take the enterprise technological innovation project as the important carrier of the talent training, and take the frontline needs of the industry enterprises as the first line. The source of the topic of the graduate design.

\section{E. Promote the construction of "new engineering", and build a training mode of production, teaching and integration}

According to the development needs of the service areas and industries, we should find out the entry points, innovation points and growth points, make the timetable and road map of deepening the integration and construction planning of production and education, clear the goals, carry out the tasks, and put forward specific ideas and measures, and make overall arrangements. By guiding college students to participate in the project of production, research and research, the training mode of closed education is changed. It makes students get more opportunities to go out of school, to enterprise, to production research practice, to stimulate innovation consciousness, cultivate innovative thinking and enhance innovation ability in practice, at the same time, enhance students' understanding of specialty, expand the perspective of students' social cognition, create more opportunities for practice and study for students, and strengthen the learning. Adapt to the society for students 


\section{CONCLUSIONS}

The integration of production and education is the leading part of the construction of "new engineering". The integration of production and education is a deep, "upgraded version" of the school enterprise cooperation. It not only promotes the government, industry, and enterprises to fulfill more social responsibilities, but also puts forward higher requirements for local universities. Local universities should change their ideas and active actions, combine their own discipline advantages and professional characteristics, study and refine the training specifications and requirements of applied undergraduate talents, deepen the reform of the training mode of applied talents, truly integrate into the regional economy, and achieve a benign interaction with the industry enterprises and develop together.

\section{ACKNOWLEDGMENT}

This study was supported by the the research project to the teaching reform of Shandong province undergraduate colleges in 2015 (No. 2015M060).

\section{REFERENCES}

[1] Y. Liu, G. Xiang, J. Wang. Research on the Model of the Fusion of Education and Industry in Application-Oriented Universities and its Influencing Factors, China Higher Education Research, no. 5, pp. 64-68, 2015.

[2] X, Shi, Y. Zhao, X. Li. The Thought of Constructing an Integration, Open and Self-daptive System of Emergent Engineering Education for Local Universities, Higher Engineering Education Research, no. 4, pp. 10-15, 2017.

[3] Y. Zhang, J. Zhou. The Demand Analysis and Development Suggestions about Integration between Industry and Education on Vocational Education, Journal of Yunnan Agricultural University (Social Science), vol. 11, no. 6, pp. 122-126, 2017.

[4] C. Xu, H. Wang. Innovation and Practice of Application - oriented Talents Training Mechanism for Environmental Protection Industry Based on Industry - education Integration, Journal of Hubei Polytechnic University, vol. 32, no. 6, pp. 61-65, 2016.

[5] P.J. Chen. Study on the Modes of Resource Integration and Utilization of Foreign Schools and Enterprises, Education Management and Management Science, vol. 7, pp. 265 -268, 2015.

[6] H. Fang. Combination between School and Locality, Teaching and Producing, Knowing and Doing: An Exploration on the Path of Cultivating Application-oriented, Journal of Yancheng Institute of Technology( Social Science Edition), vol. 30, no. 1, pp. 77-80, 2017.

[7] M. Zhang. Research on Resource Integration and Utilization Strategies of School-Enterprise in Linyi, Advances in Social Science, Education and Humanities Research, vol. 17, pp. 260-264, 2016.

[8] Y. Li, Y. Jiang. Exploration and Practice on the Cultivation of Applied Talents in the Integration of Production and Education, Heilongjiang Science, no. 4, pp. 72-73, 2018. 